\title{
Application of Information Technology Solution for Early Warning Systems at Water Utilities
}

\author{
Alicja Bałut $^{1, *}$ \\ ${ }^{1}$ Institute of Environmental Engineering, Poznan University of Technology, Berdychowo 4, 60-995, \\ Poznań, Poland.
}

\begin{abstract}
Deployment of IT solutions in water utilities in Poland concerns nowadays lots beyond GIS implementation projects [1]. The scope of modern IT platforms is truly advanced software for complete management of water treatment processes and involved objects, including ranges of various types of equipment. There are multiply factors that disrupt required volumes of supplied water. They are normally classified as natural, accidental and intentional. This paper addresses potential residing in already deployed IT solutions of water utilities in and also in new ones being now developed. Primarily- from the perspective of intentional, terrorist threats. This document depicts operating procedures that are called in case of spotted contamination in a water supply (damage of key elements of the network infrastructure) or in case of an introduction factors. This paper also discusses relevant IT tools with access provided to network operators or water plant owners that are extremely useful in accurate pinpointing the treat and in following relevant operating procedures and related actions.
\end{abstract}

\section{Introduction}

Water distribution networks are spatially highly diverse. Their exploitation depends on various external systems, including atmospheric ones. On the way water passes to end clients it meets equipment where various processes occur being a challenge for sewage plant operations. Exploitation may become a real challenge for water supply security, given each network has to meet specific physical and chemical parameters [2].

\subsection{Threats}

These events can be classified into three basic groups:

- natural (hazardous weather conditions: floods, earthquakes, fires, hurricanes, droughts, also natural contamination of ground water),

- target-oriented (terrorism, contamination with hazardous substances, acts of vandalism),

- incidental (accidents: incidental discharge of sewage or its inflow into protected areas, cracks in water pipes, accidents in areas where clean water and sewage pipelines cross).

${ }^{*}$ Corresponding address: alicja.balut@put.poznan.pl 
The amount of target-oriented (intentional) threat acts on water distribution systems or acts of sabotage of water's supply is relatively small compared to other threats listed.

Especially the following should be noted:

- destruction of water network elements via cyberattacks, mainly targeted at systems and equipment managed by SCADA (Supervisory Control and Data Acquisition),

- water contamination with: chemical substances, pharmaceuticals, microbes, bacteria, toxins. Amongst the most common points of contamination are: water tanks for treated water, main water pipelines [3].

\section{Early warning systems (EWS) in water utilities}

One of the foundations of an early warning system is its applicability to forecast diffusion of hazardous substances in a water network using a hydraulic model [4]. It is of a particular importance to note that a properly calibrated quality model has all means to become the basis to forecast, simulate diffusion of threats or simulate solutions to crisis situations and thus ensuring the security of water supply.

Above mentioned targets are as well realized by water quality monitoring systems whose purpose is to shorten the time a contaminant remains in water and as well to support the determination of spatial range of the threat. Choice of the best localisation of measuring points is a task based on multiple, often self-excluding tasks. It requires conscious decision making often supported by optimisation tools [5].

Ideal criteria of an early warning system [6],[7]:

- threat is communicated early enough to enable reaction in agreed time,

- affordable price,

- no necessity to train staff (costs),

- inclusion of all threat types,

- threat source identification,

- minimal amount of wrong answers,

- simple interface, long operation with no necessity of changes nor updates.

An early warning system consists of the following basic elements [8]:

- accident / emergency warning systems,

- hazard identification with aid of data in databases,

- hydraulic model that in case of a threat becomes the starting point for further operations,

- local water quality control system, at the source.

As mentioned above early warning systems should be based on measurements points installed at water distribution systems, water intake and measurement data received from SCADA. This information should be integrated and processed in case of threat to authorities and regional institutions [9]. Launch of such a system should be proceeded by an earlier adoption of procedures regulating alarm handling. In general prior to the deployment of an early warning system an in-depth analysis of threats related to the localization and neighborhood of the water network should be carried out [10]. Inventory should also include all available sources of emission, their category, characteristics and utilization methods. It would be also advised to carry out analysis of the risk related to acquisition of raw water.

\section{Planning and modelling of threat scenarios}

Modelling of water network systems nowadays integrated with GIS (Geographic Information Systems) enables answering key questions related to water quality:

- water sources (wells, tanks) that supply relevant city districts, 
- spot-measured water origin (percentage by sources), graphic illustration of network fragments that share water from the same source,

- time required to transport water to most remote network sections.

Figures 1,2 and 3 illustrate some screenshot from application of commercial software (InfoWater Protector, Info Works WS Plus, InfoWater) to complete similar tasks also contaminant (multiply species) modelling like [11],[12]:

- disinfection by-products model,

- pathogen inactivation model,

- chloramine decomposition model,

- particle settlement model,

- temperature.

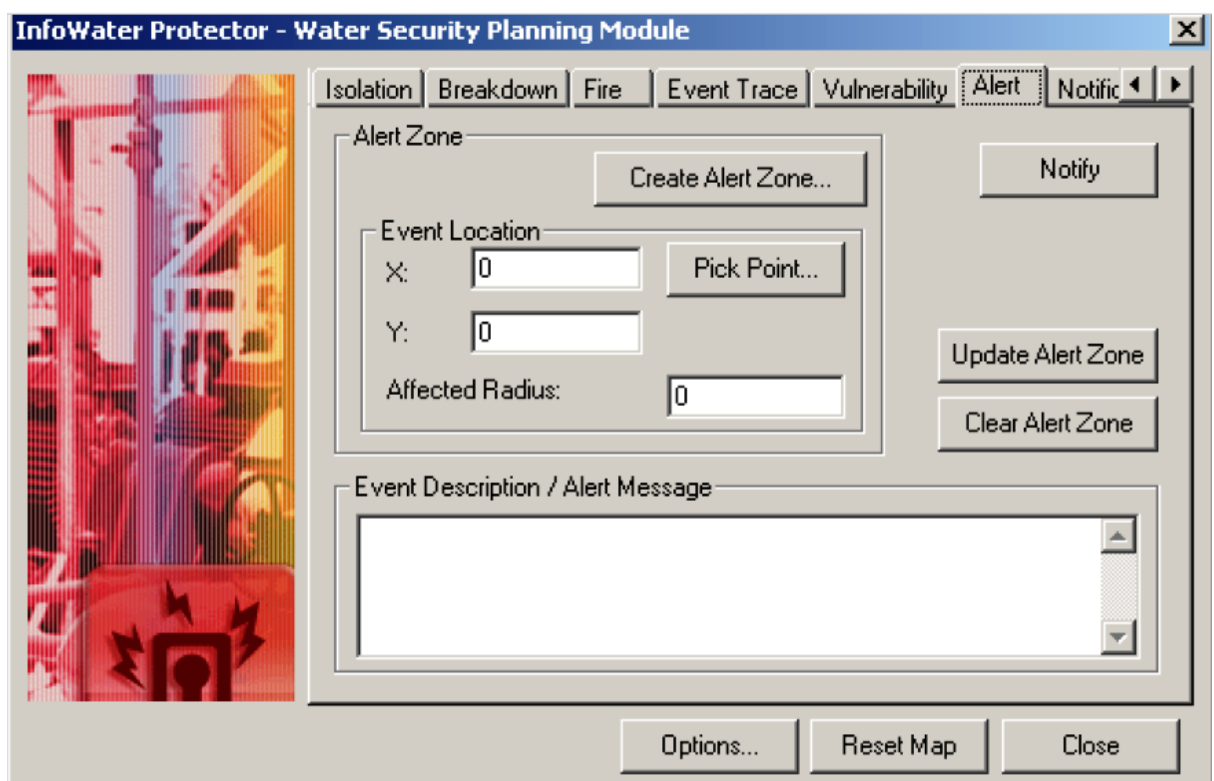

Fig. 1. Screenshot from InfoWater Protector that illustrates The ALERT tab that allows quick reporting and visualization of the extent of an event. It also supports listing of all affected customers for priority notification and sorting them in order of increasing distance (shortest to furthest) from the event location [13].

Unquestionably in case of threat related operating plans a hydraulic model is the best solution of invaluable support. Tasks mentioned above when realized during the modelling process enable generation of multiple scenarios that covered events, strategies and neutralisation techniques of i.e. substances introduced into networks on purpose. 


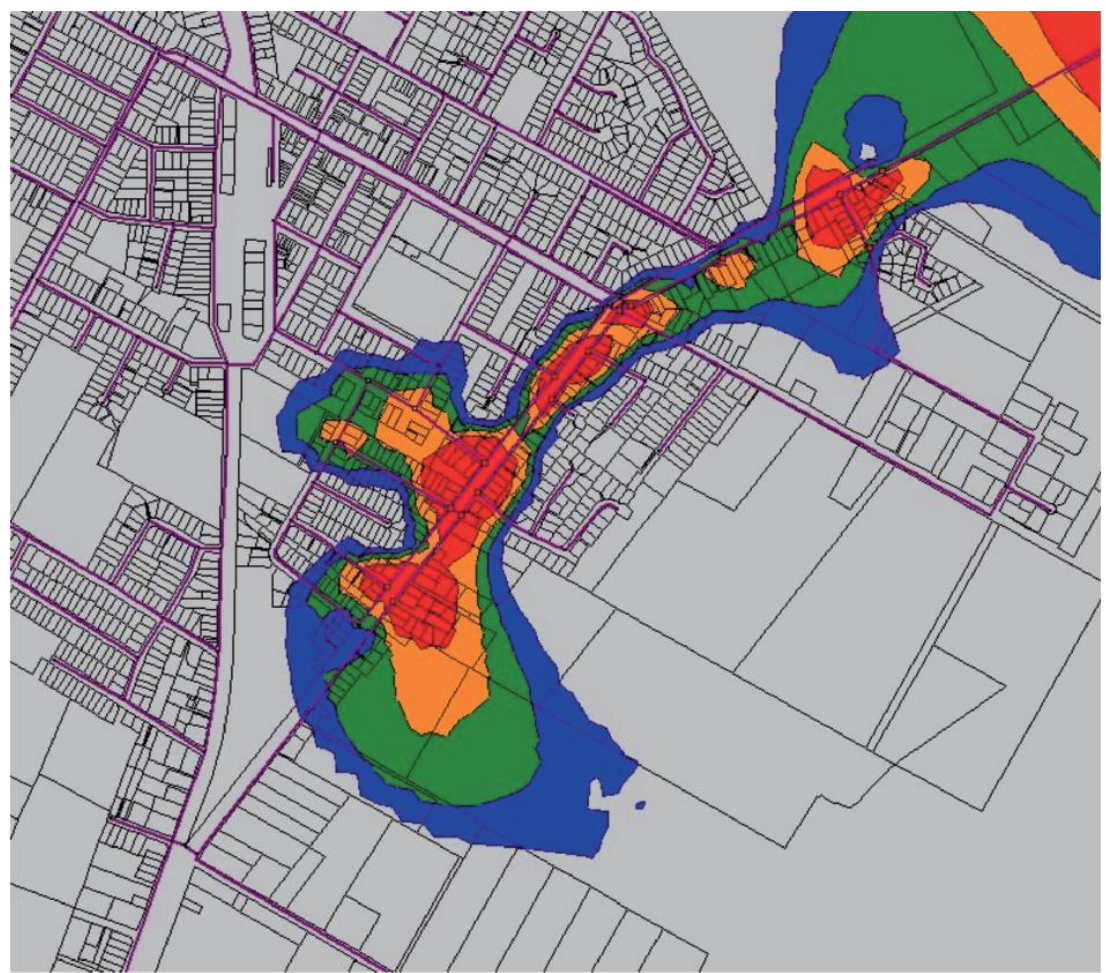

Fig. 2. Screenshot from Info Works Plus, illustrating zones with consumers of contaminated water, during the time of an incident [6].

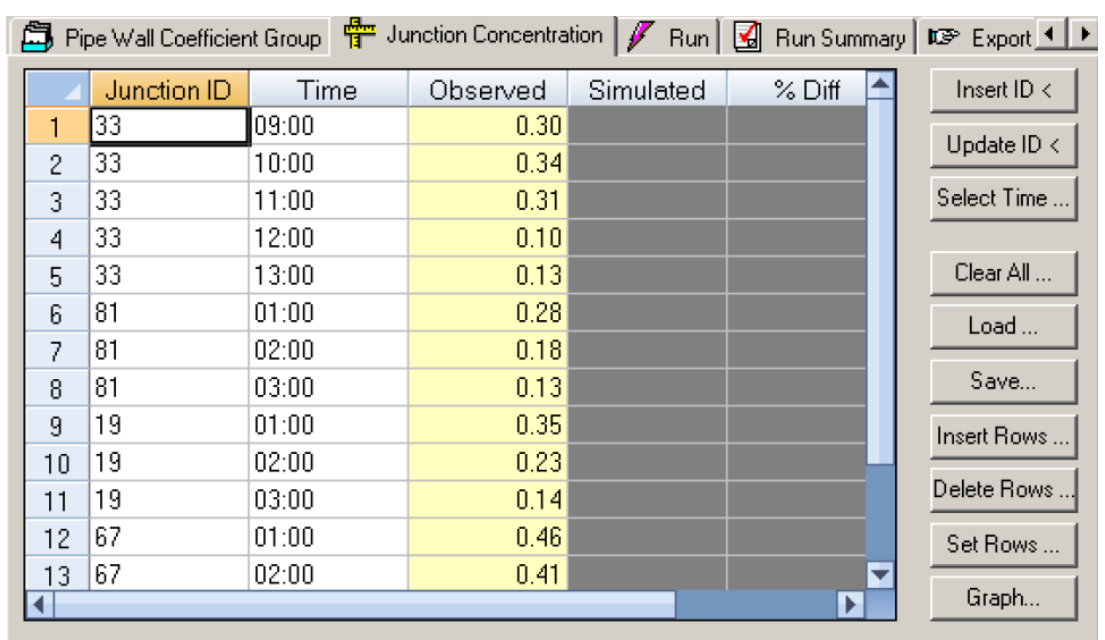

Fig. 3. Screenshot from Info Water, illustrating contaminant's accident configuration tab in a water network model [11].

Based on this example a graphical display can depict i.e.:

- zones contaminated in a given timeframe, with a given contaminant, with information on water sources,

- spot at the network map where a harmful substance has been introduced. This is available thanks to data on source type from which water in the given spot originates. 


\subsection{Emergency procedures in case of threats}

Thanks to integrated solutions - a model connected with a SCADA system and with measuring point data - automatic notifications on deviations between data computed in the model and real-life data are issued. This enables fast identification of a public security threat (number of end users of contaminated water) or a temporary break in service provisioning. Based on these analyses decisions to isolate endangered areas, their cut-off from further wide spreading of substances, aid to affected population, check of similar places (neighbouring vessels) by collection of probes for lab testing as well as other actions adequate to the threat can be made. Further information on this issue can be found at: [14],[15].

\section{Application of modelling software in early warning systems in water utilities}

In the last few years companies from the critical infrastructure sector in Poland, including water utilities, have seriously invested in IT solutions, mainly in GIS systems. This has come along with observed rapid development of enterprise management software, particularly oriented at asset maintenance. What is important from engineers' perspective, this also relates to processes 'optimisation and tools' functioning in water and sewage networks. Majority of water network utilities in Poland are in the process of implementing GIS systems. Parallel efforts are made to build hydraulic models based on EPANET.

Water distribution systems security modelling requires continual updating of network data, access and methods of collecting measurement data and taking into account operators' actions when a dangerous substance has been released into the network. In Poland, most of the utilities are facing this challenge.

Despite this article addresses a few examples of applications for modelling water networks its purpose is not to discuss IT tools for water distribution networks' monitoring. This is a spacious theme, already widely quoted in literature, that should be addressed in a separate article [16].

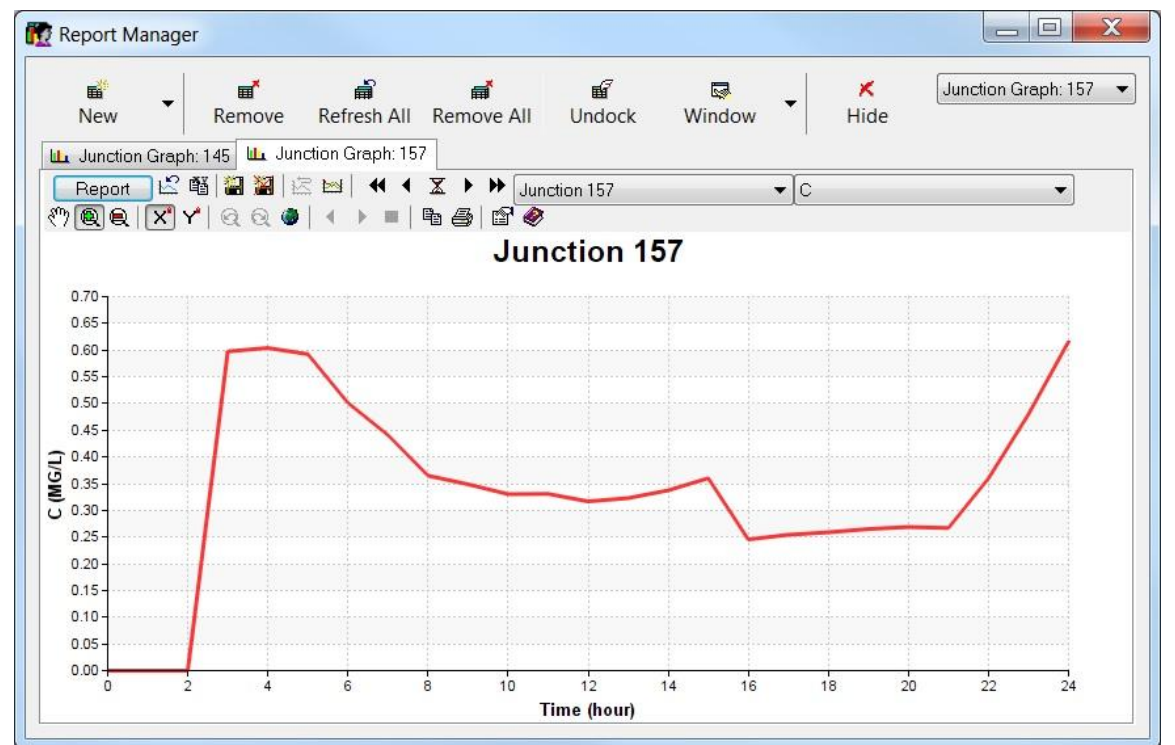

Fig. 4. Screenshot from InfoWater, that presents daily change of the water ratio from reservoir and chlorine concentration at the selected node [17]. 
Integration of SCADA systems and hydraulic modelling, nowadays called 'online modelling' enables constant modelling of pressure conditions, water flow and chosen water quality parameters in real-time and in any spot of the network [18],[19].

\section{Conclusions}

Based on briefly presented capabilities of selected IT tools it can be stated that their usability in the management of water distribution systems is sound, especially in case of incidents. Due to modern and integrated GIS, SCADA and online modelling technologies now available real-life and up-to-date data can be analysed. Thanks to these IT tools appropriate decision making can be done fast and relevant authorities/units might receive accurate data and instructions, based on pre-approved Standard Operation Procedures (SOPs). 'Time matters' - right data should be provided in right time to right addressees.

\section{References}

1. M. Sobierajski, Rewolucja informatyczna $w$ wod-kan, Ochrona Środowiska, no. 34/2011, Wrocław, (2011). pp. 16-18 (in Polish).

2. A. Kuliczkowski, D. Lichosik, Zagrożenia terrorystyczne zwiazane z systemami zaopatrzenia $w$ wodę, Instal, no. 7-8/2015, (2015), pp.77-81 (in Polish).

3. Y.Y. Haimes, N.C. Matalas, J.H. Lambert, B.A. Jackson and JRF Fellows, Reducing vulnerability of water supply systems to attack, Journal of Infrastructure Systems no. 4(4), (1998), p.164-167.

4. M. Hosner, Use of a Model to Help Secure a Water System, DHI North America Conference, Orlando, USA, June (2002), pp.1-6.

5. R. Murray, R. Janke; W.E. Hart; J.W. Berry; T. Taxon; and J. Uber; Sensor network design of contamination warning systems: a decision framework, Journal of American Water Work Association, 100(11), (2008), pp.97-109.

6. P. Ingeduld, E. Zeman, J.P. Lindgaard, M. Hornser, Real time analysis for early warning systems based on modelling concept, Water in Emergency Situations, Springer, USA, (2007), pp. 105-113.

7. [5a] M.T. Brosnan, Early warning monitoring to detect hazardous events in water supplies, An ILSI Risk Science Institute Workshop Report, (1999) ISBN: 1-57881075-2.

8. World Metrological Organization, Planning of water quality monitoring systems, Technical Report, Series no. 1113, Switzerland, (2013), pp.12-14.

9. EPA-US, Water Critical Infrastructure and Key Resources Sector-Specific Plan as Input to the National Infrastructure Protection Plan, USA, (2007), EPA 817-R-07001, pp.25-33.

10. W. Zoleński, Systemy wczesnego ostrzegania wykorzystujace wiedze, Kwartalnik Naukowy, no. 3(11), Wydawnictwo Politechniki Śląskiej, Gliwice, (2010), pp. 143161. (in Polish).

11. http://blog.innovyze.com/wp-content/uploads/2012/10/Day-2-1550-Water-SupplyWater-Quality-Modelling-Emily-Stevens.pdf (uploaded: 2012).

12. K.E. Lansey, P.F. Boulos, Comprehensive Handbook on Water Quality Analysis for Distribution Systems, MWH Soft, Pasadena, CA, USA, (2005), 448 p.

13. http://www.innovyze.com/products/infowater/protector.aspx 
14. A. Bałut, A.Urbaniak, Model sieci jako narzędzie ochrony system zaopatrzenia $w$ wodę, Gaz, woda i technika sanitarna, no. 9, (2013), pp.359-363 (in Polish).

15. M. Hosner, Use of a Model to Help Secure a Water System, DHI North America Conference, Orlando, June, (2002).

16. R.M. Clark, S. Hakim, A. Ostfeld, Handbook of Water and Wastewater Systems Protection, Springer, USA, (2011), pp.247-264.

17. InfoWater User Guide, Innovyze ${ }^{\circledR}$ Inc, Interlocken Crescent, Suite 200 Broomfield, Colorado 80021 USA, (2009), p.3-100.

18. A. Bałut, A. Urbaniak, Monitoring system as a tool for risk evaluation in water distribution systems, in: Proc. of ICCC' 2016, Ivo Petráš - Igor Podlubny - Ján Kačur (eds.) Tatranska Lomnica, Slowakia,(2016), pp. 21-24, ISBN: 978-1-4673-8605-0.

19. P. Ingeduld, G. Turton, Online analysis of water supply and water distribution systems, NZWWA Conference, Auckland, New Zealand, (2002). 